\title{
Peningkatan Kadar Hemoglobin dengan Pemberian Ekstrak Daun Salam (Syzygium Polyanthum (Wight) Walp) pada Tikus Model Anemia Defisiensi Besi
}

\author{
Kartika Adyani, ${ }^{1}$ Anita D. Anwar, ${ }^{2}$ Enny Rohmawaty ${ }^{3}$ \\ ${ }^{1}$ Program Studi D-3 Kebidanan, Fakultas Kedokteran Universitas Islam Sultan Agung Semarang, Indonesia \\ ${ }^{2}$ Departemen Obstetri dan Ginekologi Fakultas Kedokteran Universitas Padjadjaran/Rumah Sakit Hasan \\ Sadikin Bandung, Indonesia, ${ }^{3}$ Departemen Farmakologi dan Terapi Fakultas Kedokteran Universitas Padjadjaran \\ Bandung, Indonesia
}

\begin{abstract}
Abstrak
Defisiensi zat besi merupakan penyebab utama anemia di negara berkembang. Kadar hemoglobin darah digunakan sebagai penanda anemia defisiensi besi. Indonesia kaya bahan makanan tinggi zat besi namun belum diketahui kemanfaatannya seperti daun salam (Syzygium polyanthum (Wight) Walp). Tujuan penelitian ialah mengetahui peningkatan kadar hemoglobin pada tikus model anemia defisiensi besi sesudah pemberian ekstrak daun salam. Penelitian eksperimental laboratorium dengan rancang acak lengkap dilakukan di Laboratorium Farmakologi dan Terapi Fakultas Kedokteran Unpad periode 4 Mei-19 Juni 2018. Sebanyak 20 ekor tikus Wistar betina berumur 7 minggu diinduksi menggunakan alumunium sulfat 67,5 mg/kg BB secara intramuskuler selama 7 hari, dan dibagi menjadi 5 kelompok perlakuan, yaitu K1 (tanpa perlakuan) K2 (tablet tambah darah 5,4 mg), P1 (ekstrak daun salam 2,2 mg), P2 (ekstrak daun salam 4,4 mg), P3 (ekstrak daun salam 6,6 mg). Kadar hemoglobin diukur menggunakan auto hematology analyzer sysmex. Uji LSD menunjukkan rerata kadar hemoglobin setelah perlakuan pada kelompok perlakuan berbeda signifikan dibanding dengan kelompok kontrol negatif $(p<0,05)$ dan tidak berbeda signifikan dibanding dengan kelompok kontrol positif $(\mathrm{p}>0,05)$. Analisis uji median menunjukkan peningkatan kadar hemoglobin berbeda signifikan pada K2, P1, P2, dan P3 ( $<<0,05)$. Disimpulkan, ekstrak daun salam meningkatkan kadar hemoglobin pada tikus model anemia defisiensi besi.
\end{abstract}

Kata kunci: Anemia, daun salam, hemoglobin

\section{Increasing Hemoglobin Level Using Bay Leaf (Syzygium Polyanthum (Wight) Walp) Extraction in Rats Models with Iron-Deficiency Anemia}

\begin{abstract}
Iron deficiency is a major cause of anemia in developing countries. Blood hemoglobin level is used as a marker of iron-deficiency anemia. Iron-rich foods that are not widely known can easily be found in Indonesia, including bay leaf. The aim of this study was to determine the increase in hemoglobin level after the administration of bay leaf extract in rat models with iron-deficiency anemia. This experimental study used completely randomized sampling technique and was performed at Pharmacology and Therapy Laboratory, Faculty of Medicine, Universitas Padjadjaran, from 4 May to 19 June 2018. Twenty 7-week-old female Wistar rats were induced intramuscularly by $67.5 \mathrm{mg} / \mathrm{kg} \mathrm{BW}$ alumunum sulfate for 7 days and were divided into 5 groups: K1 (without treatment), K2 (5.4 mg of ferrous sulphate), P1 (2.2 mg bayleaf extract), P2 (4.4 mg bay leaf extract), P3 (6.6 mg bay leaf extract). Hemoglobin levels were measured using Auto Hematology Analyzer Sysmex. Results froom LSD test showed that the average hemoglobin levels after treatment in treatment groups were significantly different from that of the negative control group $(\mathrm{p}<0.05)$ and there was no significant difference when compared to the positive control group $(\mathrm{p}>0.05)$. The median analysis test showed that there were significant differences in the increase of hemoglobin levels among K2, P1, P2, and P3 ( $<<0.05)$. It is concluded that bay leaf simplicia increases the hemoglobin level in rat model with iron-deficiency anemia.
\end{abstract}

Key words: Anemia, bay leaf, hemoglobin

Korespondensi: Kartika Adyani, S.S.T, Program Studi D-3 Kebidanan Fakultas Kedokteran Universitas Islam Sultan Agung Semarang, Jalan Raya Kaligawe Km.4 Semarang, Email: kartika.adyani.ka@gmail.com 


\section{Pendahuluan}

Defisiensi zat besi merupakan masalah nutrisi utama di negara berkembang dan penyebab utama anemia di dunia. ${ }^{1,2}$ Lebih dari $20 \%$ wanita di dunia mengalaminya selama masa reproduksi. ${ }^{2}$ Pengendalian anemia pada wanita usia subur sangat penting untuk mencegah komplikasi anemia pada kehamilan. ${ }^{3}$ Anemia pada kehamilan dapat memberikan risiko bayi berat lahir rendah (BBLR), kelahiran prematur, kecil masa kehamilan, kelahiran mati, perdarahan, infeksi maternal, dan kematian perinatal. 3,4

Pemberian tablet tambah darah merupakan salah satu upaya untuk mengatasi anemia, namun masih belum maksimal karena berbagai hambatan seperti kurangnya kesadaran masyarakat untuk pencegahan dan pengendalian anemia, terutama untuk melakukan cek kadar hemoglobin di pusat kesehatan dan status ekonomi yang menjadi hambatan untuk mendapatkan sumber makanan kaya zat besi. ${ }^{5}$ Indonesia kaya akan bahan makanan yang kaya zat besi, namun belum diketahui oleh masyarakat luas. Salah satunya adalah daun salam yang sudah digunakan dalam masakan sehari-hari.

Bubuk daun salam kering memiliki kandungan zat besi paling tinggi, yaitu sebesar 44,1 mg/100 g dibanding dengan daun kelor $(6 \mathrm{mg} / 100 \mathrm{~g}$ ) dan bayam merah $(7 \mathrm{mg} / 100 \mathrm{~g}){ }^{6}$ Dalam 100 gram serbuk daun salam terdapat sekitar 196\% zat besi dari kebutuhan harian yang disarankan. ${ }^{7}$ Daun salam merupakan tanaman asli Indonesia yang mudah ditemukan dan dimanfaatkan oleh semua kalangan. Daun salam merupakan pohon tropis yang daunnya dikenal sebagai bumbu dan juga ramuan untuk jamu dan obat tradisional di Indonesia yang memiliki aktivitas aktioksidan. Tanaman ini memiliki kandungan yang berlimpah sehingga merupakan bahan yang menarik untuk digunakan dalam pengobatan berbagai masalah kesehatan. ${ }^{8}$

Daun salam aman dikonsumsi karena terbukti tidak menunjukkan efek toksik, teratogenitas, dan genotoksik pada hewan coba. ${ }^{9}$ Belum ada penelitian mengenai efektivitas daun salam dalam meningkatkan hemoglobin pada keadaan anemia sehingga perlu dilakukan penelitian secara in vivo untuk membuktikan efektivitas daun salam dalam meningkatkan hemoglobin. Pada penelitian ini digunakan hewan model anemia yang distimulasi memakai alumunium sulfat. Alumunium sulfat digunakan karena dapat memengaruhi proses pembentukan sel darah merah serta menghambat absorpsi zat besi dengan cara menurunkan jumlah feritin. ${ }^{10}$
Berdasar atas latar belakang tersebut penelitian ini bertujuan mengetahui peningkatan kadar hemoglobin pada tikus model anemia defisiensi besi setelah pemberian ekstrak daun salam.

\section{Metode}

Penelitian ini telah dilaksanakan di Laboratorium Farmakologi dan Terapi, Fakultas Kedokteran, Universitas Padjadjaran Bandung pada bulan Mei-Juni 2018. Persetujuan etik didapatkan dari Komite Etik Penelitian Universitas Padjadjaran Bandung dengan Nomor: 385/UN6.KEP/EC/ 2018. Daun salam didapatkan dari Balai Besar Penelitian dan Pengembangan Tanaman Obat dan Obat Tradisional (B2P2TOOT) Tawangmangu dan telah dideterminasi oleh B2P2TOOT.

Penelitian ini adalah penelitian eksperimental laboratorium dengan desain rancang acak lengkap mempergunakan 20 hewan coba Tikus galur Wistar (Rattus novergicus) yang dibagi ke dalam 5 kelompok. Kriteria inklusi adalah tikus sehat, bobot 150-200 gram, dan berumur 7 minggu sebelum adaptasi dan kriteria eksklusi berupa penurunan bobot $>10 \%$ selama masa adaptasi dan terlihat sakit.

Kelima kelompok itu diadaptasikan selama 7 hari dan selanjutnya diberikan alumunium sulfat (Prakash Chemicals International) dosis $67,5 \mathrm{mg} / \mathrm{kgBB}$ secara intramuskular selama 7 hari untuk menurunkan kadar hemoglobin. ${ }^{11}$ Pada hari ke-8 perlakuan mulai diberikan dan berlangsung selama 14 hari sesuai dengan kelompok. Pengukuran kadar pada hemoglobin dilakukan tiga kali, yaitu pada hari ke-1, ke-8, dan ke-22 pemberian perlakuan. Kadar hemoglobin diukur menggunakan auto hematology analyzer sysmex. Data kadar hemoglobin diuji secara deskriptif, uji beda rerata menggunakan uji LSD (Least Significant Difference), dan peningkatan kadar hemoglobin menggunakan uji median.

\section{Hasil}

Tikus yang telah diberi perlakuan menunjukkan peningkatan kadar hemoglobin tertinggi secara berturut-turut kelompok P3, kelompok P1, kelompok P2, kelompok K1, dan kelompok K2.

Rerata kadar hemoglobin pada kelompok perlakuan (P1, P2, P3) berbeda secara signifikan dibanding dengan kelompok kontrol negatif (K1) $(\mathrm{p}<0,05)$. Penggunaan ekstrak daun salam dengan berbagai dosis menunjukkan tidak ada 
Kartika Adyani dkk.: Peningkatan Kadar Hemoglobin dengan Pemberian Ekstrak Daun Salam (Syzygium Polyanthum (Wight) Walp

Tabel 1 Pembagian Kelompok

\begin{tabular}{|c|c|}
\hline Kelompok & Perlakuan \\
\hline K1 & Kontrol negatif dengan Na-CMC $1 \%$ \\
\hline K2 & $\begin{array}{l}\text { Kontrol positif dengan Na-CMC } 1 \%+\text { Tablet tambah darah dengan dosis } \\
5,4 \mathrm{mg}\end{array}$ \\
\hline $\mathrm{P} 1$ & Perlakuan 1 dengan Na-CMC 1\% + Ekstrak daun salam 2,2 mg \\
\hline P2 & Perlakuan 2 dengan Na-CMC 1\% + Ekstrak daun salam 4,4 mg \\
\hline P3 & Perlakuan 3 dengan Na-CMC 1\% + Ekstrak daun salam 6,6 mg \\
\hline
\end{tabular}

Tabel 2 Analisis Deskriptif Hemoglobin Setelah Perlakuan Sesuai Kelompok

\begin{tabular}{|c|c|c|c|c|}
\hline \multicolumn{2}{|c|}{ Kelompok } & \multirow{2}{*}{$\frac{\text { Hb Pre }}{10,85}$} & \multirow{2}{*}{$\frac{\text { Hb_Post }}{11,85}$} & \multirow{2}{*}{$\frac{\Delta \text { Hb Pre-Pos }}{1}$} \\
\hline K1 & Rerata & & & \\
\hline & Median & 11,1 & 12,6 & 0,8 \\
\hline & Std, Deviasi & 2,3188 & 2,9872 & 1,51877 \\
\hline & Minimum & 8,1 & 7,6 & $-0,5$ \\
\hline & Maksimum & 13,1 & 14,6 & 2,9 \\
\hline \multirow[t]{5}{*}{ K2 } & Rerata & 14,675 & 15,125 & 0,45 \\
\hline & Median & 14,3 & 15,2 & 0,7 \\
\hline & Std, Deviasi & 1,4361 & 0,8539 & 0,86987 \\
\hline & Minimum & 13,4 & 14,2 & $-0,8$ \\
\hline & Maksimum & 16,7 & 15,9 & 1,2 \\
\hline \multirow[t]{5}{*}{ P1 } & Rerata & 12,975 & 14,95 & 1,975 \\
\hline & Median & 12,9 & 15,25 & 2,4 \\
\hline & Std, Deviasi & 0,3096 & 1,4059 & 1,25 \\
\hline & Minimum & 12,7 & 13 & 0,2 \\
\hline & Maksimum & 13,4 & 16,3 & 2,9 \\
\hline \multirow[t]{5}{*}{ P2 } & Rerata & 13,45 & 15 & 1,55 \\
\hline & Median & 13,3 & 15,15 & 1,55 \\
\hline & Std, Deviasi & 1,3279 & 0,4082 & 1,28193 \\
\hline & Minimum & 12 & 14,4 & 0 \\
\hline & Maksimum & 15,2 & 15,3 & 3,1 \\
\hline \multirow[t]{5}{*}{ P3 } & Rerata & 12,35 & 15,275 & 2,925 \\
\hline & Median & 12,75 & 15,15 & 2,65 \\
\hline & Std, Deviasi & 0,9747 & 0,2872 & 0,97425 \\
\hline & Minimum & 10,9 & 15,1 & 2,1 \\
\hline & Maksimum & 13 & 15,7 & 4,3 \\
\hline
\end{tabular}




\begin{tabular}{|c|c|c|c|}
\hline & & $\begin{array}{c}\text { Perbedaan } \\
\text { Rerata }\end{array}$ & Nilai $\mathbf{p}^{*}$ \\
\hline \multirow{4}{*}{ K1 } & K2 & $-3,550$ & 0,002 \\
\hline & P1 & $-2,612$ & 0,016 \\
\hline & P2 & $-2,875$ & 0,009 \\
\hline & P3 & $-2,463$ & 0,022 \\
\hline \multirow{3}{*}{ K2 } & P1 & 0,938 & 0,345 \\
\hline & P2 & 0,675 & 0,494 \\
\hline & P3 & 1,088 & 0,276 \\
\hline \multirow{2}{*}{ P1 } & P2 & $-0,263$ & 0,789 \\
\hline & P3 & 0,15 & 0,878 \\
\hline P2 & P3 & 0,412 & 0,674 \\
\hline
\end{tabular}

"Uji LSD

perbedaan yang signifikan ( $p>0,05)$, yang berarti ekstrak daun salam dosis $2,2 \mathrm{mg}, 4,4 \mathrm{mg}$, dan 6,6 mg memberi efek yang hampir sama dalam meningkatkan kadar hemoglobin. Rerata kadar hemoglobin pada kelompok perlakuan (P1, P2, P3) tidak berbeda secara signifikan dibanding dengan kelompok kontrol positif $(K 2)(p>0,05)$ yang berarti efek pemberian ekstrak daun salam dengan berbagai dosis sebanding dengan pemberian tablet tambah darah.

Dari hasil pengujian statistik pada Tabel 4, kenaikan hemoglobin pada ketiga kelompok dosis pemberian ekstrak daun salam memiliki perbedaan bermakna apabila dibanding dengan kelompok tablet tambah darah.

Dari Tabel 5 didapatkan nilai $\mathrm{p}>0,05$ yang menunjukkan tidak ada perbedaan peningkatan

Tabel 5 Perbedaan Peningkatan Hemoglobin Antarkelompok Perlakuan

\begin{tabular}{lccc}
\hline \multirow{2}{*}{ Kelompok } & \multicolumn{2}{c}{$\begin{array}{c}\text { Peningkatan Kadar } \\
\text { Hemoglobin (gr\%) }\end{array}$} & \multirow{2}{*}{ Nilai $\mathbf{p}^{* *}$} \\
\cline { 2 - 3 } & Median & IQR & \\
\hline P1 & 2,4 & $0,65-2,87$ & 0,368 \\
P2 & 1,55 & $0,32-2,77$ & \\
P3 & 2,65 & $2,17-3,95$ & \\
\hline
\end{tabular}

\footnotetext{
${ }^{* *}$ Uji Median
}

Tabel 4 Perbedaan Peningkatan Hemoglobin
Kelompok Tablet Tambah Darah
dengan Kelompok Perlakuan

\begin{tabular}{lccc}
\hline \multirow{2}{*}{ Kelompok } & \multicolumn{2}{c}{$\begin{array}{c}\text { Peningkatan Kadar } \\
\text { Hemoglobin (g\%) }\end{array}$} & \multirow{2}{*}{ Nilai p** } \\
\cline { 2 - 3 } & Median & IQR & \\
\hline K2 & 0,7 & $-0,45-1,1$ & 0,019 \\
P1 & 2,4 & $0,65-2,87$ & \\
P2 & 1,55 & $0,32-2,77$ & \\
P3 & 2,65 & $2,17-3,95$ & \\
\hline
\end{tabular}

${ }^{\text {"NUji Median }}$

kadar hemoglobin antara kelompok tikus yang diberi ekstrak daun salam dengan dosis 2,2 mg, 4,4 mg dan dosis 6,6 mg.

\section{Pembahasan}

Pada penelitian ini diasumsikan sebelumnya bahwa ekstrak daun salam dapat meningkatkan kadar hemoglobin pada tikus model anemia. Daun salam merupakan sumber zat besi nonheme sehingga untuk mengetahui efektivitas daun salam dalam peningkatan kadar dari hemoglobin tikus pada penelitian ini terlebih dahulu dilakukan penurunan kadar hemoglobin pada hewan coba untuk menjadikan tikus model anemia defisiensi besi.

Zat penginduksi alumunium sulfat tersebut digunakan dalam pengkondisian hewan coba karena penggunaan alumunium sulfat dapat memengaruhi proses pembentukan sel darah merah serta menghambat absorbsi zat besi dengan cara menurunkan jumlah feritin sehingga anemia defisiensi besi terjadi. ${ }^{10}$

Hasil uji LSD menunjukkan bahwa kadar hemoglobin pada semua kelompok perlakuan, yaitu kelompok tikus yang diberikan ekstrak daun salam berbagai dosis $(2,2 \mathrm{mg}, 4,4 \mathrm{mg}$, dan $6,6 \mathrm{mg}$ ) berbeda signifikan dibanding dengan kadar hemoglobin pada kelompok kontrol (-), yaitu kelompok yang tidak diberikan intervensi, dan kadar hemoglobin pada semua kelompok perlakuan yang diberikan berbagai dosis ekstrak tidak berbeda signifikan dibanding dengan kadar hemoglobin pada kelompok kontrol (+), yaitu kelompok yang diberikan tablet tambah darah. Hasil ini menunjukkan bahwa kadar hemoglobin pada kelompok tikus yang diberi ekstrak daun salam dengan berbagai dosis sebanding dengan pemberian tablet tambah darah. Dapat dikatakan bahwa pemberian daun salam memberikan efek 
yang sebanding dengan pengobatan standar, yaitu tablet tambah darah.

Melihat selisih kenaikan kadar hemoglobin pada kelompok perlakuan dengan berbagai dosis ekstrak daun salam yang berbeda signifikan dibanding dengan kelompok tikus yang diberi tablet tambah darah menunjukkan bahwa selisih kenaikan hemoglobin antara kelompok berbeda. Peningkatan hemoglobin tertinggi ditemukan pada kelompok perlakuan 3 (ekstrak daun salam dengan dosis 6,6), yaitu sebesar 2,65 g\%, diikuti oleh kelompok perlakuan 1 (ekstrak daun salam dosis 2,2) sebesar 2,4 g\%, dan kelompok perlakuan 2, yaitu sebesar 1,55 g\%. Peningkatan hemoglobin pada kelompok kontrol (+) adalah sebesar $0,7 \mathrm{~g} \%$.

Berdasar atas analisis tersebut diketahui bahwa ekstrak daun salam mampu meningkatkan kadar hemoglobin yang lebih tinggi dibanding dengan kelompok yang diberikan obat standar anemia, yaitu tablet tambah darah. Dari ketiga perlakuan dengan dosis yang berbeda, dosis ekstrak daun salam 6,6 mg yang paling tinggi dalam meningkatkan kadar hemoglobin di antara dosis perlakuan yang lainnya. Walaupun demikian, melalui uji median untuk melihat perbedaan peningkatan kadar hemoglobin pada kelompok perlakuan menunjukkan bahwa dosis pemberian ekstrak daun salam tidak memberikan kadar hemoglobin yang berbeda secara signifikan sehingga dapat dikatakan bahwa ketiga dosis ekstrak daun salam yang diberikan memiliki efek yang sama. Apabila mengacu pada penggunaan obat yang rasional maka dilakukan pemilihan dosis terkecil yang memberikan efek terapi. Dosis 2,2 mg dipilih sebagai dosis efektif untuk meningkatkan kadar hemoglobin dan perlu diuji lebih lanjut agar dapat digunakan pada manusia.

Kenaikan kadar hemoglobin pada hewan coba yang diberikan ekstrak daun salam terjadi karena dalam 100 gram serbuk daun salam terkandung $44,1 \mathrm{mg}$ zat besi dan dapat memenuhi 196\% kebutuhan zat besi harian yang disarankan. ${ }^{6,7}$

Bahan pangan nabati merupakan sumber besi non-heme berbentuk ikatan ferri $\left(\mathrm{Fe}^{3+}\right)$. Besi yang berbentuk ferri akan direduksi oleh getah lambung $(\mathrm{HCl})$ menjadi bentuk ferro $\left(\mathrm{Fe}^{2+}\right)$ yang lebih mudah diserap dalam sel mukosa usus. Zat besi diserap dalam deudenum dan jejunum bagian atas melalui proses yang kompleks. Di dalam lambung, $\mathrm{Fe}^{3+}$ larut dalam asam lambung, kemudian diikat oleh gastroferin, dan direduksi menjadi $\mathrm{Fe}^{2+}$. Di dalam usus, $\mathrm{Fe}^{2+}$ mengalami oksidasi menjadi $\mathrm{Fe}^{3+}$ yang selanjutnya berikatan dengan apoferitin yang kemudian ditransformasikan menjadi feritin, dan membebaskan $\mathrm{Fe}^{2+}$ ke dalam plasma darah. Di dalam plasma, $\mathrm{Fe}^{2+}$ dioksidasi menjadi $\mathrm{Fe}^{3+}$ serta berikatan dengan transferin yang mengangkut $\mathrm{Fe}^{2+}$ ke dalam sumsum tulang untuk bergabung membentuk hemoglobin. Transferin mengangkut $\mathrm{Fe}^{2+}$ ke dalam tempat penyimpanan besi di dalam hati, sumsum tulang, limpa, dan sistem retikuloendotelial, kemudian dioksidasi menjadi $\mathrm{Fe}^{3+} \cdot{ }^{12}$

Zat lain selain zat besi yang terkandung dalam daun salam yang diduga dapat meningkatkan hemoglobin di antaranya adalah asam folat, vitamin $\mathrm{B} 12$, riboflavin, vitamin $\mathrm{B} 6$, vitamin $\mathrm{A}$, vitamin $C$, vitamin $\mathrm{E}$, dan protein. ${ }^{6,13}$ Asam folat merupakan mineral penting dalam pembentukan sel darah merah. ${ }^{14}$ Vitamin $\mathrm{C}$ meningkatkan penyerapan zat besi non-heme. ${ }^{15}$

Vitamin A memengaruhi pengeluaran zat besi dari hati. Suplementasi vitamin A dengan zat besi memperbaiki status vitamin A dan memperbaiki status zat besi. ${ }^{16}$ Vitamin E berperan sebagai antioksidan asam lemak untuk pembentukan membran sel sehingga dinding sel tidak mudah pecah. Rapuhnya dinding sel darah merah diduga menyebabkan suplementasi zat besi tidak efektif. Penambahan vitamin E pada suplementasi fero sulfat dan asam folat meningkatkan kekuatan dinding sel darah merah 3 kali lipat dibanding dengan suplementasi tanpa vitamin E. Penambahan vitamin E dalam suplementasi zat besi juga dapat meningkatkan kadar hemoglobin 1,5 kali lebih besar dibanding dengan suplementsi tanpa vitamin E. ${ }^{17}$

Protein berperan penting dalam transportasi zat besi di dalam tubuh. Kurangnya asupan protein dalam tubuh akan dapat mengakibatkan transportasi zat besi terhambat dan terjadi defisiensi besi. Semakin rendah asupan protein dan asupan zat besi, semakin rendah pula kadar hemoglobin. ${ }^{18}$ Keterbatasan penelitian ini adalah tidak seragamnya kadar hemoglobin awal pada semua kelompok tikus yang akan diberikan perlakuan. Simpulan penelitian ini adalah ekstrak daun salam dapat meningkatan kadar hemoglobin pada tikus model anemia defisiensi besi. Peningkatan kadar hemoglobin pada kelompok perlakuan ekstrak daun salam lebih tinggi dibanding dengan pemberian tablet tambah darah.

\section{Daftar Pustaka}

1. Alaofe H, Burney J, Naylor R, Taren D. Anemia, iron and vitamin a deficits are still 
public health issues among women and young children in northern benin. FASEB J. 2016;30(1 Supplement):892.10-.10.

2. Percy L, Mansour D, Fraser I. Iron deficiency and iron deficiency anaemia in women. Best Practice Research Clin Obstet Gynaecol. 2017;40:55-67.

3. Kumar KJ, Asha N, Murthy DS, Sujatha M, Manjunath V. Maternal anemia in various trimesters and its effect on newborn weight and maturity: an observational study. International journal of preventive medicine. 2013;4(2):193-9.

4. Haider BA, Olofin I, Wang M, Spiegelman D, Ezzati M, Fawzi WW. Anaemia, prenatal iron use, and risk of adverse pregnancy outcomes: systematic review and meta-analysis. BMJ: 2013;346.

5. Balarajan Y, Ramakrishnan U, Ozaltin E, Shankar AH, Subramanian SV. Anaemia in low-income and middle-income countries. Lancet. 2011;378(9809):2123-35.

6. Persatuan Ahli Gizi Indonesia. Tabel komposisi pangan Indonesia. Jakarta: PAGI; 2017.

7. Dayod M, Abat M. Nutritional and antioxidant properties of young aromatic shoots of Bungkang, [Syzygium polyanthum] (wight) Walp. J Plant Pathol Microbiol. 2017;8:5 (Suppl):1.

8. Kato E, Nakagomi R, Gunawan-Puteri MD, Kawabata J. Identification of hydroxychavicol and its dimers, the lipase inhibitors contained in the Indonesian spice, Eugenia polyantha. Food Chem. 2013;136(3):1239-42.

9. Jumaat SR, Tajuddin SN, Sudmoon R, Chaveerach A, Abdullah UH, Mohamed R. Chemical constituents and toxicity screening of three aromatic plant species from Peninsular Malaysia. BioResources. 2017;12(3):5878-95.

10. Adnyana IK, Rosmadi A, Sigit JI, Rahmawati SF. Pengaruh pemberian jus daun katuk, jus daun ubi jalar, dan kefir terhadap profil hematologi mencit anemia yang diinduksi alumunium sulfat. Acta Pharmaceutica Indonesia. 2012;37(2):54-8.

11. Ganchev T, Dyankov E, Zacharieva R, Pachalieva I, Velikova M, Kavaldjieva B. Influence of aluminium on erythropoiesis, iron metabolism and some functional characteristics of erythrocytes in rats. Acta Physiol Pharmacol Bulg. 1998;23(1):27-31.

12. Santiago P. Ferrous versus ferric oral iron formulations for the treatment of iron deficiency: a clinical overview. ScientificWorldJournal. 2012;2012:846824.

13. Prahastuti S, Tjahjani S, Hartini E. The effect of bay leaf infusion (Syzygium polyanthum (Wight) Walp) to decrease blood total cholesterol level in dyslipidemia model wistar rats. Jurnal Medika Planta. 2011; 1(4).27-32

14. Akhtar M, Hassan I. Severe anaemia during late pregnancy. Case Reports in Obstetrics and Gynecology. 2012;2012:485452.

15. Utama TA, Listiana N, Susanti D. Perbandingan zat besi dengan dan tanpa vitamin c terhadap kadar hemoglobin wanita usia subur. Kesmas: National Public Health Journal. 2013;7(8):344-8.

16. Ridwan E. Kajian interaksi zat besi dengan zat gizi mikro lain dalam suplementasi (review of interactions between iron and other micronutrients in supplementation). penelitian gizi dan makanan. Penel Gizi Makan. 2012;35(1):49-54 .

17. Saidin M, Sukati S, Muherdiyatiningsih M, Rustan E. Pengaruh pemberian tablet besi dan vitamin e pada kadar hemoglobin dan status besi wanita usia subur yang diduga menderita thalasemia karier. PGM. 2003;26(2):1-9.

18. Al Rahmad AH. Pengaruh asupan protein dan zat besi (Fe) terhadap kadar hemoglobin pada wanita bekerja. Jurnal Kesehatan. 2017;8(3): 321-5. 